\title{
The cyclicality of government foreign-aid expenditure: voter awareness in "good" times and in "bad"
}

\author{
Andrew Abbott ${ }^{1}$ D. Philip Jones ${ }^{2}$
}

Received: 8 October 2018 / Accepted: 26 November 2019 / Published online: 16 December 2019

(c) The Author(s) 2019

\begin{abstract}
While it has been argued that the cyclicality of government spending likely depends on the intensities of political pressure to increase expenditure, in economic upturns and downturns, it is important to explore the determinants of changes in the strengths of those pressures. This paper is the first (to our knowledge) to focus on the relevance of systematic changes in voter awareness of government spending. Predictions of the impact of changes in awareness are tested with reference to 23 OECD donor countries' foreign aid expenditures over the 1999-2015 period. The evidence offers insights into the discretion governments exercise when "fiscal illusion" increases and into the policy implications of systematic changes in voter awareness (in "good" times and in "bad").
\end{abstract}

Keywords Government expenditure · Foreign aid · Fiscal illusion · Voracity effects

JEL Classification $\mathrm{E} 62 \cdot \mathrm{H} 50 \cdot \mathrm{H} 60 \cdot \mathrm{H} 70$

\section{Introduction}

Economists usually anticipate countercyclical government spending (Alesina et al. 2008), but evidence is mounting that governmental outlays are procyclical (Gavin et al. 1996; Kaminsky et al. 2004; Talvi and Végh 2005; Woo 2009). Public expenditure is procyclical if it increases as national income increases and declines as national income declines. While circumstances exist in which procyclical expenditure can maximize a community's welfare (Lane 2003), such circumstances are very specific and extremely unlikely (Halland and Bleaney 2011). ${ }^{1}$ The growing consensus is that systematic changes in political

\footnotetext{
1 When markets are working perfectly and when public-sector and private-sector goods are complements, procyclical government expenditure might maximize a community's welfare (e.g., Lane 2003).
}

Andrew Abbott

a.abbott@hull.ac.uk

Philip Jones

p.r.jones@bath.ac.uk

1 Lancaster University, Bailrigg, Lancaster LA1 4YW, UK

2 Department of Economics, University of Bath, Bath, UK 
pressures over the economic cycle are determinants of procyclical public expenditure. Lane and Tornell (1996) and Tornell and Lane (1999) refer to "voracity effects". When "voracity effects" operate, political pressures to increase public spending are more intense in economic upturns than in economic downturns.

In this paper, the first objective is to explore the question why are political pressures for increased public spending more intense in economic upturns? If income effects are positive, spending pressures are likely to strengthen as income increases, but when "voracity effects" operate additional factors must be considered. The proposition to be considered in Sect. 2 is that systematic changes in voter awareness (of fiscal policy) are relevant when explaining changes in the intensities of political pressures for more government spending.

Empirical studies have indicated that donor governments' provision of foreign aid is procyclical. Dabla-Norris et al. (2015) report that foreign aid flows are influenced positively by the output gap between the donor country and recipient countries. GravierRymaszewska (2012) explored the effects of macroeconomic shocks on the supply of foreign aid from donor countries, reporting evidence that aid budgets fall when own revenues fall. By comparison, in this paper, the second objective is to test the proposition that systematic changes in voter awareness over the economic cycle influence changes in the intensity of political pressure (for more foreign aid) and the cyclicality of that budget item.

In Sect. 2 the first question is whether it is possible to call on the public choice literature to predict systematic differences in voters' awareness over time. Can we conclude that marked differences exist in voter awareness in "good times" and in "bad"?

1. In economic upturns, voters are more likely to underestimate the effects of increases in taxation (Dell'Anno and Dollery 2014; Dell'Anno and Mourao 2011; Dollery and Worthington 2006; Oates 1988). In economic upturns, government revenue is increasing. New taxes need not be introduced, nor existing tax rates raised, to accommodate pressure for more public spending. Consequently, vote-maximizing governments have wider discretion to increase government expenditure. Governments find it easier to accommodate lobby groups knowing that voters are not aware of the tax implications of lobbying (Downs 1957). Governments also are able to exercise discretion in pursuing their own ideological goals if discretion means that their preferred spending on some programs exceeds the median voter's preferred spending. When income is increasing and when the tax implications are not apparent, voters are sanguine about public expenditure.

2. In economic downturns (as in any social crisis), the evidence is that voters are far more aware of government spending. Peacock and Wiseman (1961, p. xxiv) refer to the inspection effect. When a social crisis (e.g., a recession) is underway, voters may question whether the government has spent sufficiently on domestic government programs (e.g., healthcare, education).

Given the foregoing dichotomy, the intention herein is to focus on the impact of changes in voter awareness of public spending (1) in upturns and (2) in downturns. The cyclicality of expenditure over the full economic cycle will reflect different experiences when the economy is expanding or contracting. In that way, the paper is the first (to our knowledge) to employ a methodology that focuses separately on different cyclicalities (in upturns and in downturns) to explain the overall cyclicality of expenditure. The paper is also the first to consider the likelihood that vote-maximizing governments respond strategically to "fiscal illusion" in economic upturns. To date, the literature on "fiscal illusion" in economic upturns has focused on its impact on the level of aggregate public expenditure. Here, the 
proposition is that, as vote-maximizing governments benefit from a systematic reduction in voter awareness, they are likely strategically to time increases in potentially "unpopular" expenditures during economic upturns. Does evidence exist of that strategy (if governments are under pressure to accommodate lobby groups to increase public expenditure beyond the preference of the median voter) $?^{2}$

Testable predictions are presented in Sect. 2 of the paper. Later sections present the data and empirical model employed to test the predictions. The intention is to test each of the predictions separately, but a further (and more demanding) question is whether the overall pattern of cyclicality (across budgets) is consistent with the pattern of cyclicality predicted in Sect. 2.

While the paper focuses on the cyclicality of government spending, it also sheds insight on the broader issue of governance. How are governments likely to respond to evidence of greater or lesser "fiscal illusion"? How are they likely to respond in "good" times and in "bad"?

\section{Are systematic changes in "voter awareness" relevant when explaining the cyclicality of government foreign-aid expenditure?}

While changes in income are likely to be relevant when explaining changes in government expenditure, political pressures also are likely to influence changes in such spending. ${ }^{3}$ How is the intensity of political pressure for more public spending likely to change in economic upturns and in downturns?

\subsection{Fiscal awareness in economic upturns}

If vote-maximizing governments are aware of greater "fiscal illusion" in economic upturns, they also have an incentive to time increases in foreign aid expenditures during those "good times". Two motivations can be identified:

1. Governments are more likely to win votes by increasing expenditure when voters are least aware of the spending's tax implications.

2. Governments have more opportunities for pursuing their own objectives when voters' attentions are not focused on taxation. Government policy usually is analyzed in terms of: (1) governments' responses to voters' preferences and (2) governments' own political preferences (e.g., Cusack 1997; Keech 1995; Wittman 1983).

When focusing on foreign aid, governments have an incentive to time increases in that spending when voters are least aware of their effects because: (1) voters underestimate the benefits of foreign aid (Heinrich et al. 2016) and (2) overestimate its costs

\footnotetext{
2 To date, the literature on 'fiscal illusion' has focused on governmental incentives to increase the level of public spending, but this paper is the first to argue that 'fiscal illusion' also is likely to exert an influence on the composition of government spending.

${ }^{3}$ Heinrich et al. (2016) note that even when international aid has been reduced in a recession, aggregate government expenditures have increased.
} 
(Heinrich and Kobayashi 2018). In some cases, governments also have an additional incentive to time increases in spending during economic upturns because they have their own ideological reasons to expand foreign aid. Evidence has been reported that leftwing governments prefer to spend more than the median voter does on foreign aid (see e.g., Milner and Tingley 2013).

The opportunity for governments to act strategically exists because of greater "fiscal illusion" in economic upturns. An established literature indicates that voters are not as aware of taxation in economic upturns (Abbott and Jones 2013; Dell'Anno and Mourao 2011; Dollery and Worthington 2006; Oates 1988). With progressive tax schedules, voters underestimate spending's effects on taxation when national income is rising (Craig and Heins 1980). In economic upturns, they also are more likely to underestimate taxation's effects, the larger is the income elasticity of tax revenue (Abbott and Jones 2016). When national income is increasing, it thus is easier politically to increase government expenditures. In economic downturns, the reverse is true; voters are more sensitive to taxation and to the prospect of increases in taxation. Andersen and Nielsen (2010) demonstrate that, in the OECD, a "lack of fiscal transparency" is more prevalent in economic upturns than in economic downturns.

To test the proposition that governments act strategically, our analysis focuses on whether governments have both the motivation and the opportunity to behave in that way. With reference to motivation, the evidence is that left-wing governments spend more on foreign aid, but (to date) no specific evidence has been reported that left-wing governments systematically spend more in economic upturns. The first prediction is therefore that:

\section{Left-wing governments are more likely to increase aid expenditures procyclically in economic upturns.}

The motivation to take advantage of "fiscal illusion" in economic upturns is likely to be more important for governments (of all political persuasions), the smaller are their electoral majorities. Questionnaire responses make it clear that, when voters are asked to prioritize government spending, foreign aid is the last item on their list (Abbott and Jones 2019). An existing literature reveals that governments are more sensitive to the preferences of the median voter (and less inclined to pursue their own ideological goals) the smaller are the sizes of their popular majorities (Frey and Schneider 1978, 1981). In this paper, the second prediction is that:

2. Governments with smaller electoral majorities are more likely to increase aid expenditures procyclically in economic upturns.

Of course, the significance of the opportunities that governments have (to take advantage of "fiscal illusion") depends on whether or not other influences are in play in economic upturns. One such event is a forthcoming election. Voters are less likely to be as unaware of fiscal changes in an election year (as political parties compete for their votes). In the runup to an election, voters are likely to pay far more attention to public spending and taxes. The implication is that:

\section{Governments are not as likely to spend procyclically in an economic upturn during an election year.}


Collectively, the foregoing predictions test the proposition that governments are more likely to exercise discretion by increasing expenditures when public officials enjoy an informational advantage over voters. When no such "informational advantage" exists (e.g., because taxes are discussed during an electoral campaign), the incentives strategically to time spending increases during economic upturns are weaker.

\subsection{Fiscal awareness in recessions}

In recessions, voters are more likely to be aware of changes in government expenditure. Governments can be receptive when voters are more attentive to fiscal policies, particularly prior to elections (Rogoff 1990). Evidence likewise has been found that governments increase consumption expenditure prior to an election at the expense of capital expenditure (see e.g., Katsimi and Sarantides 2012).

In recessions, governments have the motivation to be more sensitive to voters' spending priorities. As taxpayers struggle to pay taxes, the apathy (created by automatic increases in tax revenues in economic upturns) is replaced by concern that governments will not be able to sustain all spending programs. With falling tax revenues and more difficulties in borrowing, governments find it harder to accommodate pressures to increase aggregate government expenditure. However, the opportunity exists in recessions to divert expenditure from some public-sector programs to others.

Downs (1960) argued that governments spend "too little" on all international programs because they prioritize domestic expenditures, which deliver private benefits that are more tangible and immediate in voters' day-to-day lives. Downs (1960, p. 561) argued that complexity and the remoteness of benefits from government expenditure is obvious "in international affairs where economic and technical progress have spread a web of interdependency over the whole world". The question is, do domestic expenditures fare "better" in recessions and do they do so at the expense of expenditures on foreign aid?

The existing literature suggests a number of reasons to expect that governments are likely to reduce expenditure on foreign aid during economic contractions:

1. Perceptions of the "tax price": In a recession, taxpayers likely will revise their perceptions of the "tax price" of government programs. ${ }^{4}$ When governments rely on general taxation, voters can focus on one "tax price". Their response to the perception that the "tax price" is higher than expected will depend on the price elasticity of demand for different government-provided goods and services.

The seminal estimates of the price elasticities of domestic government services by Borcherding and Deacon (1972) and Bergstrom and Goodman (1973) indicate that the price elasticity is less than one. With a marginal increase in the "tax price", such price inelasticity requires an increase in expenditure even when the demand for public-sector output falls. By comparison, estimates of the price elasticity for international aid exceed one. Steinberg (1990, p. 69) notes that estimates of the price elasticity of charitable giving "were almost always greater than 1". Only a very small minority of studies have

\footnotetext{
4 As earned incomes become more unequal in recessions those who remain in employment will become more aware of the costs of taxation (Abbott and Jones 2011). If progressive taxation disguises the true costs of taxation to those who move into higher income brackets in economic upturns, in recessions there is a proportionate increase in the tax burden for those who avoid unemployment.
} 
indicated that giving is price inelastic. ${ }^{5}$ Peloza and Steel (2005) survey the literature and report their own estimate of the price elasticity as - 1.44. Peloza and Steel (2005, p. 267) conclude that "a decrease in $\$ 1$ in the costs of giving can be expected to result in more than $\$ 1$ being donated to charity". Moreover, estimates of the price elasticity of international giving are even higher. Hossain and Lamb (2012) report a price elasticity as high as -2.12 . If voters revise the "tax price" upwards, with such a price elasticity, no pressure to increase government expenditure on foreign aid will be forthcoming (when the demand for international giving falls). The immediate response to the perception that the "tax price" is higher than anticipated is that a smaller expenditure on international aid is sufficient.

2. Perceptions of "adequacy": In a recession, voters question the adequacy of domestic government expenditure. In their renowned analysis of the growth of public expenditure, Peacock and Wiseman (1961) argued that in a recession an "inspection effect" arises. The crisis "force(s) the attention of governments and peoples to problems of which they were formerly less conscious". In that context:

(a) In a recession, voters become more "isolationist" (Almond 1960).With reference to giving foreign aid in a recent UK recession, (Heinrich et al. 2016, p. 68) cite the response of Patrick Mercer (a Member of Parliament): "I believe most people are tolerant of spending money overseas until it comes to some of the more telling elements of that spending. For instance, many in my constituency would take serious exception to millions of pounds being spent on foreign schools when our own secondary schools are tumbling down around our kids' ears". More generally, Fuchs et al. (2014, p. 177) note that "aid provision can be expected to give rise to fiercer opposition at times of lower or even negative GDP growth and increasing unemployment...".

(b) In a recession, the demand for domestic government services increases. Both mental and physical health can deteriorate in recessions (Ariizumi and Schirle 2012; Modrek et al. 2013). Similarly, voters' awareness of the relevance of education in securing employment is heightened in economic recessions.

(c) In a recession, governments are more sensitive to the observation that domestic "multiplier effects" (in terms of income and employment) are larger than foreign "multiplier effects". Governments are aware of the over-riding pressure in recessions to reduce unemployment and to stabilize the economy. Jones and Hudson (1996) estimate the electoral importance of voters' perceptions that politicians are able to manage the economy over the economic cycle.

\footnotetext{
${ }^{5}$ Gruber (2004) refers to the consensus in the $1970 \mathrm{~s}$ and $1980 \mathrm{~s}$ that the price elasticity of charitable giving was found to be greater than one in absolute value terms. While in the 1990s, a distinction was made between transitory and permanent changes, to suggest that the permanent price elasticity was lower, Gruber (2004, p. 2640) argues that a "more sophisticated decomposition of permanent and transitory effects" now indicates, that even in the case of a permanent price elasticity, estimates are in the range of -0.8 to -1.26 . In this paper, attention focuses on the transitory changes.
} 
Which two or three, if any, of the following main areas of public spending do you think should be protected from any cuts?

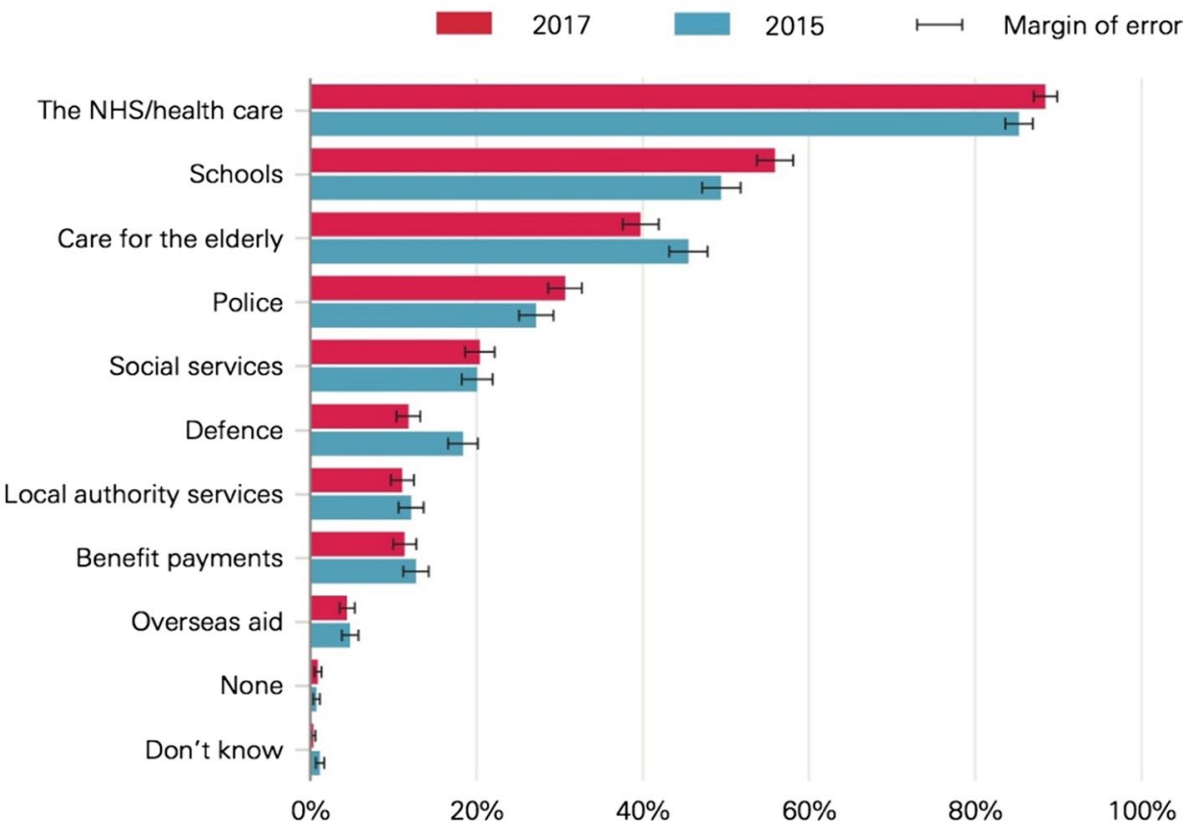

Fig. 1 Voters' priorities to sustain expenditures in recessions

Both perceptions of changes in the "tax price" and of the adequacy of domestic services can influence voters' priorities. Figure 1 reports responses to a questionnaire survey undertaken in the United Kingdom by Market and Opinion Research International (MORI) (and reported by the Health Foundation 2017). While more than $80 \%$ of voters in 2015 and 2017 identified the importance of retaining expenditure on health care, only 5\% identified foreign aid as a program to be protected from spending cuts. No identical questionnaire surveys exist across the OECD, but similar studies for other countries support the UK findings. For example, in the 1995 Program on International Policy Attitudes poll (PIPA 2001), conducted in the United States, $64 \%$ of respondents favored reducing foreign aid. US voters also overestimated the costs of foreign aid. In February 2001, 40\% of respondents from the same poll favored cutting foreign aid. ${ }^{6}$

With tax and borrowing constraints in recessions, governments must rely more heavily on the option of diverting expenditures. Consequently, we expect:

4. Donor countries' government international aid expenditures are likely to be more procyclical in economic recessions than domestic current government expenditures.

\footnotetext{
${ }^{6}$ Evidence of similar political priorities can be found in other OECD countries. For example, in 2007, $90 \%$ of respondents in Australia expressed a preference for more spending on health (Wilson et al. 2012). In the United States, between 1960 and 2001, "public support for increased health spending ... met with increases in health expenditure" (Soroka and Lim 2003, p. 576). Ramji and Quiñonez (2012) also document the public's prioritization of government health services in Canada.
} 


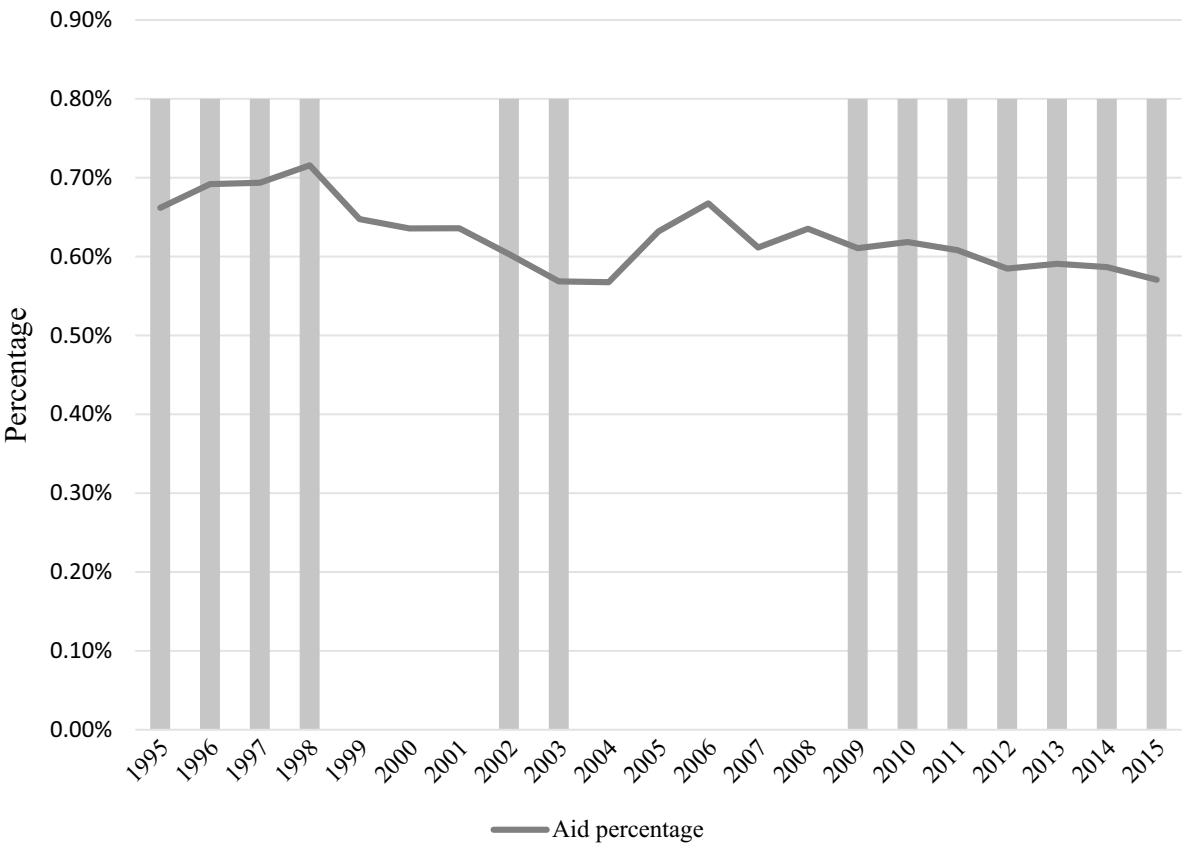

Fig. 2 Foreign aid as a percentage of total spending. Notes Shaded areas denote economic downturns i.e. where $\Delta \mathrm{y}_{\text {it }}<0$. Source: OECD International Development Statistics

5. Donor countries' government aid expenditures are likely to be more procyclical in economic recessions than current expenditures on social security.

If vote-maximizing governments are more sensitive to voters' priorities during recessions, the composition of government spending across government programs will change systematically in recessions.

\subsection{The "ratcheting effect" of government responses in "good times" and in "bad"}

When focusing on functional expenditures (e.g., international aid), the question is whether cyclical changes are likely to exert a "ratchet up" (or "ratchet down") effect on the longterm delivery of services.

Hercowitz and Strawczynski (2004) present an empirical framework that offers insight into the impact of cyclical changes in public outlays on prolonged changes in government spending. ${ }^{7}$ They reported that increases in government spending in recessions in the OECD were only partially reduced in economic upturns. The "ratchet effect" for aggregate government spending therefore was positive.

Focusing on functional budgetary line items like international aid, the same technique can be applied to estimate the net effect of the cyclicality of any government expenditure.

\footnotetext{
7 Higgs (1987) provided a classic assessment of the impact of "ratcheting effects" when he analysed the growth of government in the USA.
} 
Figure 2 illustrates changes in government international aid in the OECD between 1995 and 2015. The shaded areas indicate the periods during which the output gap for the OECD as a whole was negative. In 2002, 2003 and from 2009 to 2015 there were recessions accompanied by a decrease in government expenditure on foreign aid.

As the predictions are that government international aid will be procyclical in upturns and also in downturns, the question is whether cyclical increases compensate for cyclical reductions. To explore that question, the final testable prediction is:

6. The government's response to fiscal illusion in economic upturns will be sufficient to produce a positive "ratchet effect" on the long-term provision of government international aid expenditures.

\section{Testing predictions: models and data}

To investigate the cyclical properties of foreign aid expenditure we estimate ${ }^{8}$ :

$$
\Delta \mathrm{fa}_{\mathrm{it}}=\beta_{1} \Delta \mathrm{fa}_{\mathrm{it}-1}+\beta_{2} \Delta \mathrm{fa}_{\mathrm{it}-2}+\beta_{3} \Delta \mathrm{y}_{\mathrm{it}}+\beta_{4} \Delta \mathrm{y}_{\mathrm{it}-1}+\beta_{5} \Delta \mathrm{y}_{\mathrm{it}-2}+\mu_{i}+\lambda_{t}+\varepsilon_{\mathrm{it}},
$$

where $\mathrm{fa}_{\mathrm{it}}$ is the natural $\log$ of foreign economic aid expenditure for donor country $\mathrm{i}$ in period t, observations on which are taken from the Government Expenditure by Function section of the General Government Accounts (OECD 2018a), part of the OECD National Accounts (OECD 2018b). Foreign economic aid is a component of the broader General Public Services function and is defined as the government's total aid budget, which is allocated to all purposes and given to all recipients. ${ }^{9}$ It is a relatively small part of total expenditure, averaging only $0.6 \%$ of all government spending across the sample and $4.7 \%$ of the larger General Public Services function. The change in income, $\Delta \mathrm{y}_{\mathrm{it}}$, reflects the economic cycle and while the literature sometimes uses the first difference in real GDP, we use the more common output gap, figures for which come from the OECD's Economic Outlook: Statistics and Projections (OECD 2018c). All series are collected for a sample of 23 donor countries ${ }^{10}$ over the period from 1999 to 2015 and expressed in constant prices using data on the GDP deflator (OECD 2018b). We enter lagged values of $\Delta \mathrm{fa}_{\mathrm{it}}$ to account for potential persistence in the growth of foreign economic aid budgets; $\Delta \mathrm{y}_{\mathrm{it}-1}$ and $\Delta \mathrm{y}_{\mathrm{it}-2}$ also are entered since the cyclical relationship between GDP and government spending on foreign economic aid might not be contemporaneous, e.g., owing to information lags. Our focus nevertheless remains on the contemporaneous relationship between $\Delta \mathrm{y}_{\text {it }}$ and $\Delta \mathrm{fa}_{\mathrm{it}}$, along with how the $\beta_{3}$ coefficient estimates the cyclicality of foreign aid spending. A finding that $\beta_{3}<0$ indicates that aid spending is countercyclical; $\beta_{3}>0$ suggests procyclical expenditure; while if $\Delta y_{i t}$ is found not to be statistically significant then aid expenditures are acyclical. Unobservable heterogeneity is accounted for by including time fixed effects $\lambda_{\mathrm{t}}$ and country-specific fixed effects $\mu_{\mathrm{i}}$. Given the presence of lagged dependent variables

\footnotetext{
8 Similar cyclicality equations have been estimated by, for example, Akitoby et al. (2006) and Lane (2003).

${ }^{9}$ Further details on the definition of foreign economic aid, which is distributed to developing countries and countries in transition, as well as international organizations, can be found at: https://unstats.un.org/unsd/cr/ registry/regcs.asp?Cl=4\&Lg=1\&Co=01.2.

10 The countries are Austria; Belgium; the Czech Republic; Denmark; Estonia; Finland; France; Germany; Hungary; Ireland; Italy; Japan; Luxembourg; Netherlands; Norway; Poland; Portugal; Slovak Republic; Slovenia; Spain; Sweden; Switzerland and the United Kingdom.
} 
and the potential for finite sample bias (Nickell 1981) our preferred estimator is the System Generalized Method of Moments (SYS-GMM) (Blundell and Bond 1998). We also calculate robust standard errors for hypothesis testing, after adjusting for clustering in the donors. SYS-GMM estimates are said to be consistent if serial correlation is absent at second order or higher (though first-order serial correlation is anticipated) and if the instruments employed are valid. We test each of those assumptions for the models estimated in the following section. While our chosen estimator can control partially for potential endogeneity of the independent variables, the SYS-GMM instruments may not control fully for potential endogeneity of the output gap. We therefore enter the following instruments: contemporaneous oil price inflation in national currency terms; the lagged output gap for the whole of the OECD; and the contemporaneous change in exports as a percentage of GDP (e.g., Darby and Melitz 2008), which account for the influence of external exogenous shocks on the domestic output gap. The data for those additional instruments come from the U.S. Energy Information Administration (2019) and (OECD 2018c).

While foreign aid might be procyclical over the business cycle, asymmetries in the cyclical response could exist between economic upturns and downturns. We can test for differences in the cyclical responses of spending between upturns and downturns by estimating the following equation:

$$
\begin{aligned}
\Delta \mathrm{fa}_{\mathrm{it}}= & \alpha_{1} \Delta \mathrm{fa}_{\mathrm{it}-1}+\alpha_{2} \Delta \mathrm{fa}_{\mathrm{it}-2}+\alpha_{3} \Delta \mathrm{y}_{\mathrm{it}}^{+}+\alpha_{4} \Delta \mathrm{y}_{\mathrm{it}-1}^{+}+\alpha_{5} \Delta \mathrm{y}_{\mathrm{it}-2}^{+} \\
& +\alpha_{6} \Delta \mathrm{y}_{\mathrm{it}}^{-}+\alpha_{7} \Delta \mathrm{y}_{\mathrm{it}-1}^{-}+\alpha_{8} \Delta \mathrm{y}_{\mathrm{it}-2}^{-}+\mu_{i}+\lambda_{t}+\varepsilon_{\mathrm{it}} .
\end{aligned}
$$

The specification of (2) differs from (1) by including $\Delta \mathrm{y}_{\mathrm{it}}^{+}$and $\Delta \mathrm{y}_{\mathrm{it}}^{-}$, as well as the associated lagged terms, which enables us to test for differences in the cyclical responses of aid spending between upturns and downturns. Upturns are defined as periods when the actual level of output is above the trend level, i.e., a positive output gap $\left(\Delta \mathrm{y}_{\mathrm{it}}^{+}\right)$, whereas downturns are periods when actual output is below trend, i.e., a negative output gap $\left(\Delta \mathrm{y}_{\text {it }}^{-}\right)$. So $\Delta \mathrm{y}_{\text {it }}^{+} \neq 0$ and equals $\Delta \mathrm{y}_{\mathrm{it}}^{+}$, when $\Delta \mathrm{y}_{\text {it }}^{+}$takes a positive value and zero otherwise, while $\Delta \mathrm{y}_{\mathrm{it}}^{-} \neq 0$ (and equals $\Delta \mathrm{y}_{\mathrm{it}}^{-}$) when $\Delta \mathrm{y}_{\mathrm{it}}^{-}$takes a negative value and zero otherwise.

The above equations can be extended to test the extent to which governments rely on economic upturns to influence aid spending patterns. Our first hypothesis, that "leftwing governments are more likely to increase aid expenditures procyclically in economic upturns", can be tested by estimating:

$$
\begin{aligned}
\Delta \mathrm{fa}_{\mathrm{it}}= & \sum_{\mathrm{j}=1}^{2} \delta_{1 \mathrm{j}} \Delta \mathrm{fa}_{\mathrm{it}-\mathrm{j}}+\sum_{\mathrm{j}=0}^{2} \delta_{2 \mathrm{j}} \Delta \mathrm{y}_{\mathrm{it}-\mathrm{j}}^{+}+\sum_{\mathrm{j}=0}^{2} \delta_{3 \mathrm{j}} \Delta \mathrm{y}_{\mathrm{it}-\mathrm{j}}^{-}+\delta_{4} \mathrm{lft}_{\mathrm{it}} \\
& +\sum_{\mathrm{j}=0}^{2} \delta_{5 \mathrm{j}}\left(\Delta \mathrm{y}^{+} \times \mathrm{lft}\right)_{\mathrm{it}-\mathrm{j}}+\sum_{\mathrm{j}=0}^{2} \delta_{6 \mathrm{j}}\left(\Delta \mathrm{y}^{-} \times \mathrm{lft}\right)_{\mathrm{it}-\mathrm{j}}+\mu_{i}+\lambda_{t}+\varepsilon_{\mathrm{it}} .
\end{aligned}
$$

Specification (3) extends (2) by entering the dummy variable $\mathrm{fft}_{\mathrm{it}}$, as well as the interaction terms $\left(\Delta \mathrm{y}^{+} \times \mathrm{lft}\right)$ and $\left(\Delta \mathrm{y}^{-} \times \mathrm{lft}\right)$, where lft is a dummy variable that equals one whenever the government is classified as "left-wing". Data on the ideological preferences of governments come from the Database of Political Institutions 2017 (Scartascini et al. 2018), which classifies countries based on party orientations with respect to economic policy. Countries are classified as "left-wing" when they are categorized as "communist, socialist, social democratic, or left-wing" (Ibid., p. 8); the alternatives are "right" or "center". Support for hypothesis (1) arises when $\left(\Delta \mathrm{y}^{+} \times \mathrm{lft}\right)$ is statistically significant and $\delta_{50}>0$. 
Similarly, we can test the influence of the government's electoral majority on the cyclicality of foreign aid spending during economic upturns (hypothesis (2)) by entering the interaction terms $\left(\Delta y^{+} \times\right.$maj $)$and $\left(\Delta y^{-} \times\right.$maj), where maj is the "fraction of seats held by the government" (Scartascini et al. 2018):

$$
\begin{aligned}
\Delta \mathrm{fa}_{\mathrm{it}}= & \sum_{\mathrm{j}=1}^{2} \lambda_{1 \mathrm{j}} \Delta \mathrm{fa}_{\mathrm{it}-\mathrm{j}}+\sum_{\mathrm{j}=0}^{2} \lambda_{2 \mathrm{j}} \Delta \mathrm{y}_{\mathrm{it}-\mathrm{j}}^{+}+\sum_{\mathrm{j}=0}^{2} \lambda_{3 \mathrm{j}} \Delta \mathrm{y}_{\mathrm{it}-\mathrm{j}}^{-}+\lambda_{4} \mathrm{maj}_{\mathrm{it}} \\
& +\sum_{\mathrm{j}=0}^{2} \lambda_{5 \mathrm{j}}\left(\Delta \mathrm{y}^{+} \times \mathrm{maj}\right)_{\mathrm{it}-\mathrm{j}}+\sum_{\mathrm{j}=0}^{2} \lambda_{6 \mathrm{j}}\left(\Delta \mathrm{y}^{-} \times \text {maj }\right)_{\mathrm{it}-\mathrm{j}}+\lambda_{7} \mathrm{elec}_{\mathrm{it}} \\
& +\sum_{\mathrm{j}=0}^{2} \lambda_{8 \mathrm{j}}\left(\Delta \mathrm{y}^{+} \times \text {elec }\right)_{\mathrm{it}-\mathrm{j}}+\sum_{\mathrm{j}=0}^{2} \lambda_{9 \mathrm{j}}\left(\Delta \mathrm{y}^{+} \times \text {elec }\right)_{\mathrm{it}-\mathrm{j}}+\mu_{i}+\lambda_{t}+\varepsilon_{\mathrm{it}} .
\end{aligned}
$$

Governments with smaller majorities are more likely to increase aid spending procyclically during economic upturns, so $\left(\Delta \mathrm{y}^{+} \times\right.$maj $)$should be statistically significant and the estimated coefficient $\lambda_{50}$ negatively signed. Equation (4) also can be used to test the influence of elections from hypothesis (3) from the $\left(\Delta \mathrm{y}^{+} \times\right.$elec $)$and $\left(\Delta \mathrm{y}^{-} \times\right.$elec $)$terms, where "elec" equals one during election years and zero otherwise. Data on the election years comes from Scartascini et al. (2018), who reports information on the years remaining in the current term (elections are those periods with zero years left). Support for the hypothesis "governments are not as likely to spend procyclically in an economic upturn in an election year" arises when $\left(\Delta y^{+} \times\right.$elec $)$is statistically insignificant.

To compare the cyclicality of foreign aid with the cyclicality of domestic and social security spending, we estimate:

$$
\begin{aligned}
\Delta \mathrm{de}_{\mathrm{it}}= & \varphi_{0}+\varphi_{1} \Delta \mathrm{de}_{\mathrm{it}-1}+\varphi_{2} \Delta \mathrm{de}_{\mathrm{it}-2}+\varphi_{3} \Delta \mathrm{y}_{\mathrm{it}}^{+}+\varphi_{4} \Delta \mathrm{y}_{\mathrm{it}-1}^{+}+\varphi_{5} \Delta \mathrm{y}_{\mathrm{it}-2}^{+} \\
& +\varphi_{6} \Delta \mathrm{y}_{\mathrm{it}}^{-}+\varphi_{7} \Delta \mathrm{y}_{\mathrm{it}-1}^{-}+\varphi_{8} \Delta \mathrm{y}_{\mathrm{it}-2}^{-}+\mu_{i}+\lambda_{t}+\varepsilon_{\mathrm{it}} \\
\Delta \mathrm{sp}_{\mathrm{it}}= & \tau_{0}+\tau_{1} \Delta \mathrm{sp}_{\mathrm{it}-1}+\tau_{2} \Delta \mathrm{sp}_{\mathrm{it}-2}+\tau_{3} \Delta \mathrm{y}_{\mathrm{it}}^{+}+\tau_{4} \Delta \mathrm{y}_{\mathrm{it}-1}^{+}+\tau_{5} \Delta \mathrm{y}_{\mathrm{it}-2}^{+} \\
& +\tau_{6} \Delta \mathrm{y}_{\mathrm{it}}^{-}+\tau_{7} \Delta \mathrm{y}_{\mathrm{it}-1}^{-}+\tau_{8} \Delta \mathrm{y}_{\mathrm{it}-2}^{-}+\mu_{i}+\lambda_{t}+\varepsilon_{\mathrm{it}},
\end{aligned}
$$

where the variable de denotes domestic expenditures and $s p$ refers to expenditure on social protection. Domestic expenditure is the sum of spending on health, education and social protection, with observations taken from the OECD's Government Expenditure by Function database (OECD 2018a). From hypotheses (4) and (5), foreign aid expenditure is expected to be more procyclical than both domestic expenditure and social protection, implying that $\Delta \mathrm{y}_{\text {it }}$ should be statistically significant and the cyclicality coefficient on foreign economic aid, $\alpha_{6}$ in (2), positive and larger in magnitude than $\varphi_{6}$ from (5) and $\tau_{6}$ in (6).

Our sixth hypothesis tests whether the cyclical pattern of foreign economic aid exerts a permanent effect on the level of such spending. The $\alpha$ coefficients in (2) capture spending patterns in expansions and contractions. When the cyclical pattern is asymmetric, spending will react differently to $\Delta \mathrm{y}^{+}$and $\Delta \mathrm{y}^{-}$. For example, if governments respond to growing tax revenues during expansions by increasing spending but choose not to contract spending when tax revenues fall during contractions, such behavior will increase spending levels over time, through cyclical upward ratcheting (Hercowitz and Strawczynski 2004). To measure the importance of that spending 
mechanism, we can calculate the ratcheting coefficient from (2), which is given by $\Phi=\left(\alpha_{3}+\alpha_{4}+\alpha_{5}\right)-\left(\alpha_{6}+\alpha_{7}+\alpha_{8}\right)$ (see Hercowitz and Strawczynski (2004). The value of $\Phi$ and its statistical significance will determine whether spending ratchets upwards or downwards.

\section{Estimation results}

Table 1 presents the descriptive statistics for the variables used in the empirical analysis, as well as the sources for the economic time series used. Before turning to the estimation results for our hypotheses it is useful to comment on the overall cyclical properties of foreign aid spending across the economic cycle. The evidence from our sample suggests that $\Delta \mathrm{y}_{\mathrm{it}}$ is statistically significant from estimating (1) and that foreign aid is procyclical, since we find that $\beta_{3}>0$, with an estimated coefficient of $0.063 .{ }^{11}$ The full estimation results are available upon request.

To test our first hypothesis, "Left-wing governments are more likely to increase aid expenditures procyclically in economic upturns", the results of estimating (3) are reported in Table 2. We find that the interaction term $\left(\Delta \mathrm{y}^{+} \times 1 \mathrm{ft}\right)_{\text {it }}$ is statistically significant and the coefficient estimate is positive, implying a larger procyclical marginal effect from left-wing governments during economic upturns, compared to all other political ideologies. Utilizing the estimates for $\Delta \mathrm{y}_{\mathrm{it}}$ and $\left(\Delta \mathrm{y}^{+} \times \mathrm{lft}\right)_{\mathrm{it}}$, we can conclude that during periods of left-wing governments, $\Delta \mathrm{y}_{\mathrm{it}}$ is statistically significant and the estimated cyclicality coefficient for foreign aid spending is 0.218 , while for the other ideologies $\Delta \mathrm{y}_{\text {it }}$ is statistically insignificant, implying that foreign aid is acyclical; the estimated coefficient is 0.099 .

To consider the influence of government majorities on the cyclicality of foreign aid expenditures we estimate (4), the results from which also are shown in Table 2. Consistent with our prediction that "governments with smaller electoral majorities are more likely to increase aid expenditures procyclically in economic upturns", we find that the interaction term $\left(\Delta y^{+} \times \text {maj }\right)_{\text {it }}$ is statistically significant and that the estimated coefficient is negatively signed. Smaller values of maj are consistent with narrower majorities for the incumbent government; the negatively signed estimated coefficient implies that as the majority gets smaller the extent of procyclicality rises for foreign aid. If the proportion of the seats held by the government falls by one standard deviation, then the marginal gain to procyclicality is 0.0661 , which is relatively modest compared to the cyclicality estimate of 0.426 for $\Delta \mathrm{y}_{\mathrm{it}}^{+}$. The results from (4) also are supportive of the prediction that "Governments are not as likely to spend procyclically in an economic upturn in an election year", since we find that $\left(\Delta \mathrm{y}^{+} \times \text {elec }\right)_{\text {it }}$ is not statistically significant.

Hypotheses (4) and (5) indicate that during economic recessions foreign economic aid spending should be more procyclical than (1) domestic expenditures and (2) social security. The results of estimating Eqs. (2), (5) and (6) are presented in Table 3. Evidence in support

\footnotetext{
11 Dabla-Norris et al. (2015) find that the level of foreign aid flows is positively influenced by the output gap of the donor and recipient countries, though this is not a direct test for procyclicality like ours, which uses the first difference of foreign aid expenditures as the dependent variable. Similarly, GravierRymaszewska (2012) considers the influence of macroeconomic shocks on the supply of foreign aid from donor countries. Aid budgets are shown to respond to economic crises through lower fiscal revenues and by raising fiscal costs through exchange rates and financial volatility. Political ideology is in turn shown to influence the aid allocation process: "right-wing and centre governments cut aid in response to economic distress while left-wing governments may not" (Gravier-Rymaszewska 2012, p. 42).
} 


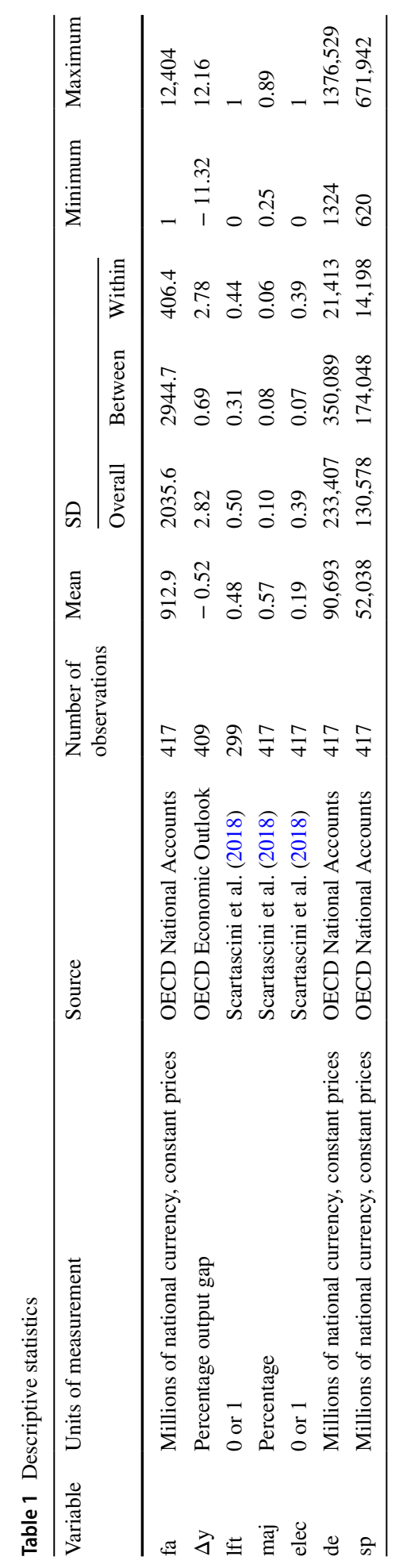


Table 2 The influence of political ideology, government majority and election years on the cyclicality of foreign economic aid

\begin{tabular}{|c|c|c|c|}
\hline \multicolumn{2}{|l|}{ Variable } & \multicolumn{2}{|l|}{ Variable } \\
\hline$\Delta \mathrm{fa}_{\mathrm{it}-1}$ & $\begin{array}{l}-0.892^{*} \\
(-44.06)\end{array}$ & $\Delta \mathrm{fa}_{\mathrm{it}-1}$ & $\begin{array}{l}-0.914^{*} \\
(-40.45)\end{array}$ \\
\hline$\Delta \mathrm{fa}_{\mathrm{it}-2}$ & $\begin{array}{l}-0.523 * \\
(-25.0)\end{array}$ & $\Delta \mathrm{fa}_{\mathrm{it}-2}$ & $\begin{array}{l}-0.561^{*} \\
(-40.54)\end{array}$ \\
\hline$\Delta y_{i t}^{+}$ & $\begin{array}{l}0.099 \\
(1.85)\end{array}$ & $\Delta \mathrm{y}_{\mathrm{it}}^{+}$ & $\begin{array}{l}0.426^{*} \\
(2.28)\end{array}$ \\
\hline$\Delta \mathrm{y}_{\mathrm{it}-1}^{+}$ & $\begin{array}{l}0.044 \\
(1.06)\end{array}$ & $\Delta \mathrm{y}_{\mathrm{it}-1}^{+}$ & $\begin{array}{l}-0.163 \\
(-1.62)\end{array}$ \\
\hline$\Delta \mathrm{y}_{\mathrm{it}-2}^{+}$ & $\begin{array}{l}0.195 \\
(1.43)\end{array}$ & $\Delta \mathrm{y}_{\mathrm{it}-2}^{+}$ & $\begin{array}{l}0.847^{*} \\
(3.51)\end{array}$ \\
\hline$\Delta y_{i t}^{-}$ & $\begin{array}{l}0.114^{*} \\
(2.78)\end{array}$ & $\Delta \mathrm{y}_{\mathrm{it}}^{-}$ & $\begin{array}{l}0.064 \\
(0.41)\end{array}$ \\
\hline$\Delta \mathrm{y}_{\mathrm{it}-1}^{-}$ & $\begin{array}{l}-0.002 \\
(-0.09)\end{array}$ & $\Delta y_{i t-1}^{-}$ & $\begin{array}{l}-0.014 \\
(-0.10)\end{array}$ \\
\hline$\Delta \mathrm{y}_{\mathrm{it}-2}^{-}$ & $\begin{array}{l}-0.118 \\
(-1.44)\end{array}$ & $\Delta \mathrm{y}_{\mathrm{it}-2}^{-}$ & $\begin{array}{l}0.027 \\
(0.18)\end{array}$ \\
\hline lft & $\begin{array}{l}-0.060 \\
(-0.68)\end{array}$ & maj & $\begin{array}{l}-0.795 \\
(-1.39)\end{array}$ \\
\hline$\left(\Delta y^{+} \times 1 \mathrm{lt}\right)_{\mathrm{it}}$ & $\begin{array}{l}0.118^{*} \\
(2.54)\end{array}$ & $\left(\Delta y^{+} \times \text {maj }\right)_{\text {it }}$ & $\begin{array}{l}-0.661^{*} \\
(-2.17)\end{array}$ \\
\hline$\left(\Delta y^{+} \times 1 \mathrm{ft}\right)_{\mathrm{it}-1}$ & $\begin{array}{l}-0.055 \\
(-1.48)\end{array}$ & $\left(\Delta \mathrm{y}^{+} \times \mathrm{maj}\right)_{\mathrm{it}-1}$ & $\begin{array}{l}0.275 \\
(1.60)\end{array}$ \\
\hline$\left(\Delta \mathrm{y}^{+} \times 1 \mathrm{lft}\right)_{\mathrm{it}-2}$ & $\begin{array}{l}-0.089 \\
(-1.02)\end{array}$ & $\left(\Delta y^{+} \text {maj }\right)_{\text {it }-2}$ & $\begin{array}{l}-1.406^{*} \\
(-3.30)\end{array}$ \\
\hline$\left(\Delta y^{-} \times 1 \mathrm{lft}\right)_{\text {it }}$ & $\begin{array}{l}-0.103^{*} \\
(-2.32)\end{array}$ & $\left(\Delta y^{-} \times \text {maj }\right)_{i t}$ & $\begin{array}{l}-0.032 \\
(-0.13)\end{array}$ \\
\hline$\left(\Delta y^{-} \times 1 \mathrm{lft}\right)_{\mathrm{it}-1}$ & $\begin{array}{l}0.042 \\
(1.22)\end{array}$ & $\left(\Delta y^{-} \times \text {maj }\right)_{\text {it }-1}$ & $\begin{array}{l}0.003 \\
(0.01)\end{array}$ \\
\hline \multirow[t]{8}{*}{$\left(\Delta y^{-} \times 1 f t\right)_{i t-2}$} & $\begin{array}{l}0.077 \\
(1.52)\end{array}$ & $\left(\Delta y^{-} m_{a j}\right)_{i t-2}$ & $\begin{array}{l}-0.022 \\
(-0.09)\end{array}$ \\
\hline & & elec & $\begin{array}{l}-0.039 \\
(-0.43)\end{array}$ \\
\hline & & $\left(\Delta \mathrm{y}^{+} \times \text {elec }\right)_{\text {it }}$ & $\begin{array}{l}0.040 \\
(0.79)\end{array}$ \\
\hline & & $\left(\Delta \mathrm{y}^{+} \times \text {elec }\right)_{\mathrm{it}-1}$ & $\begin{array}{l}0.012 \\
(0.40)\end{array}$ \\
\hline & & $\left(\Delta \mathrm{y}^{+} \times \text {elec }\right)_{\mathrm{it}-2}$ & $\begin{array}{l}0.028 \\
(1.09)\end{array}$ \\
\hline & & $\left(\Delta y^{-} \times \text {elec }\right)_{\text {it }}$ & $\begin{array}{l}-0.067 \\
(-1.72)\end{array}$ \\
\hline & & $\left(\Delta y^{-} \times \text {elec }\right)_{\mathrm{it}-1}$ & $\begin{array}{l}-0.004 \\
(-0.16)\end{array}$ \\
\hline & & $\left(\Delta \mathrm{y}^{-} \times \text {elec }\right)_{\mathrm{it}-2}$ & $\begin{array}{l}-0.049 \\
(-0.87)\end{array}$ \\
\hline $\mathrm{N} \times \mathrm{T}$ & 222 & $\mathrm{~N} \times \mathrm{T}$ & 336 \\
\hline No. of instruments & 66 & No. of instruments & 73 \\
\hline $\operatorname{SC}(1): \chi^{2}(1)$ & $-2.00^{*}$ & $\operatorname{SC}(1): \chi^{2}(1)$ & $-2.64 *$ \\
\hline $\mathrm{SC}(2): \chi^{2}(2)$ & -0.56 & $\mathrm{SC}(2): \chi^{2}(2)$ & 0.56 \\
\hline $\operatorname{SC}(4): \chi^{2}(4)$ & 0.48 & $\operatorname{SC}(4): \chi^{2}(4)$ & -0.48 \\
\hline Hansen: $\chi^{2}(31)$ & 0 & Hansen: $\chi^{2}(31)$ & 0 \\
\hline
\end{tabular}


Table 2 (continued)

T-ratios, that are calculated from robust standard errors, are shown in parentheses. *Indicates significance at the 5\% level. The number of instruments displayed refers to the number of SYS-GMM instruments, as well as the additional instruments that are used to control for potential endogenity of the output gap. The autocorrelation tests are for zero autocorrelation in first-differenced errors at first order ( $\mathrm{SC}(1))$, second order (SC(2)) and fourth-order (SC(4)). The Hansen test of over-identifying restrictions is reported

Table 3 The cyclicality of foreign aid, domestic and social protection expenditures

\begin{tabular}{|c|c|c|c|}
\hline Variable & Foreign economic aid & Domestic expenditure & Social protection \\
\hline$\Delta \mathrm{fa}_{\mathrm{it}-1}$ & $\begin{array}{l}-0.932 * \\
(-44.67)\end{array}$ & - & - \\
\hline$\Delta \mathrm{fa}_{\mathrm{it}-2}$ & $\begin{array}{l}-0.569^{*} \\
(-40.32)\end{array}$ & - & - \\
\hline$\Delta \mathrm{de}_{\mathrm{it}-1}$ & - & $\begin{array}{l}-0.174 \\
(-1.29)\end{array}$ & - \\
\hline$\Delta \mathrm{de}_{\mathrm{it}-2}$ & - & $\begin{array}{l}-0.198 \\
(-1.88)\end{array}$ & - \\
\hline$\Delta \mathrm{sp}_{\mathrm{it}-1}$ & - & - & $\begin{array}{l}-0.458^{*} \\
(-2.76)\end{array}$ \\
\hline$\Delta \mathrm{sp}_{\mathrm{it}-2}$ & - & - & $\begin{array}{l}-0.369 * \\
(-6.18)\end{array}$ \\
\hline$\Delta \mathrm{y}_{\mathrm{it}}^{+}$ & $\begin{array}{l}0.080 * \\
(2.15)\end{array}$ & $\begin{array}{l}0.005^{*} \\
(2.78)\end{array}$ & $\begin{array}{l}0.004 \\
(1.38)\end{array}$ \\
\hline$\Delta \mathrm{y}_{\mathrm{it}-1}^{+}$ & $\begin{array}{l}0.002 \\
(0.06)\end{array}$ & $\begin{array}{l}-0.0005 \\
(-0.16)\end{array}$ & $\begin{array}{l}-0.001 \\
(-0.40)\end{array}$ \\
\hline$\Delta \mathrm{y}_{\mathrm{it}-2}^{+}$ & $\begin{array}{l}0.194 * \\
(2.14)\end{array}$ & $\begin{array}{l}-0.0009 \\
(-0.14)\end{array}$ & $\begin{array}{l}0.011 \\
(1.30)\end{array}$ \\
\hline$\Delta \mathrm{y}_{\mathrm{it}}^{-}$ & $\begin{array}{l}0.071 * \\
(1.96)\end{array}$ & $\begin{array}{l}0.004 \\
(1.49)\end{array}$ & $\begin{array}{l}-0.0008 \\
(-0.32)\end{array}$ \\
\hline$\Delta \mathrm{y}_{\mathrm{it}-1}^{-}$ & $\begin{array}{l}-0.046 \\
(-1.18)\end{array}$ & $\begin{array}{l}0.001 \\
(0.37)\end{array}$ & $\begin{array}{l}0.003 \\
(1.01)\end{array}$ \\
\hline$\Delta \mathrm{y}_{\mathrm{it}-2}^{-}$ & $\begin{array}{l}-0.022 \\
(-0.45)\end{array}$ & $\begin{array}{l}-0.008^{*} \\
(-2.06)\end{array}$ & $\begin{array}{l}-0.006 \\
(-0.71)\end{array}$ \\
\hline $\mathrm{N} \times \mathrm{T}$ & 336 & 363 & 363 \\
\hline No. of instruments & 59 & 59 & 59 \\
\hline $\mathrm{SC}(1): \chi^{2}(1)$ & $-2.10^{*}$ & $-2.87 *$ & $-2.66^{*}$ \\
\hline $\mathrm{SC}(2): \chi^{2}(2)$ & -0.71 & 1.90 & $2.65^{*}$ \\
\hline $\mathrm{SC}(4): \chi^{2}(4)$ & 0.18 & -1.51 & -0.74 \\
\hline Hansen: $\chi^{2}(57)$ & 0 & 0 & 0 \\
\hline
\end{tabular}

See Table 2

of our hypotheses comes from finding that $\Delta \mathrm{y}_{\text {it }}^{-}$is statistically significant only for foreign aid spending; the estimated coefficient is 0.071 . Both domestic current expenditures and social security spending are found to be acyclical during economic downturns. It is interesting to note that the cyclicality coefficients for foreign economic aid are of broadly similar magnitudes during upturns and downturns. We tested whether the cyclicality coefficients 
are statistically significantly different from one another i.e. $\mathrm{H}_{0}: \alpha_{3}-\alpha_{6}=0$. The difference in the estimated coefficients is only 0.009 and the associated Z-statistic is 0.16 , which implies that we cannot reject the null hypothesis, and so conclude that the cyclical response of foreign economic aid is symmetric across economic upturns and downturns.

Finally, we consider whether the cyclical pattern of spending has a permanent influence on the level of spending for foreign economic aid (hypothesis (6)). Using the estimates presented in Table 3, the cyclical ratcheting coefficient is calculated to be 0.273 ; the estimated standard error is 0.121 . The standard $t$ test therefore is 2.26 , implying significance at the 5\% level. From that result, we can infer that foreign aid spending will be $0.27 \%$ higher at the end of the cycle compared to its beginning. While the estimated coefficient is smaller than earlier estimates of the ratcheting coefficient given for total spending in the OECD [see e.g., Hercowitz and Strawczynski (2004), who present a ratchet coefficient of 1.07], the result remains important in demonstrating the long-term consequences arising from the cyclicality of foreign aid spending. We derived that value since, during upturns, the combined coefficients of $\left(\alpha_{3}+\alpha_{4}+\alpha_{5}\right)$ yield an estimate of 0.273 , implying that for a one percentage rise in the positive output gap, foreign economic aid rises by $0.27 \%$. By contrast for the economic downturns, the combined cyclicality coefficients are only $\left(\alpha_{6}+\alpha_{7}+\alpha_{8}\right)=0.003$, suggesting that the contraction in foreign economic aid is far smaller during the economic downturns than its increase in the upturns.

\section{Conclusions}

The initial motivation for this paper was the observation that procyclical public spending might be explained with reference to "voracity effects" (Lane and Tornell 1996; Tornell and Lane 1999). If political pressures to increase government spending are more intense in economic upturns than downturns, why are political pressures more intense in the former than in the latter?

The methodology employed herein differs from methodologies applied elsewhere that focus on the cyclicality of government expenditures. The usual approach is to analyze the cyclicality of government expenditure over a full economic cycle. However, in this paper it also is important to distinguish between cyclicality in upturns versus downturns. Our new approach offers additional insight because, even if two government spending programs are described as "procyclical", important differences are likely if: (1) one set of expenditure is procyclical because it is procyclical in both upturns and downturns and (2) the other is procyclical because spending is highly procyclical in upturns and simply acyclical in downturns. In this paper, the evidence is that, between 1999 and 2015, OECD governments' foreign aid expenditures were procyclical over a complete economic cyclical and procyclical in both economic upturns and recessions.

Analysis of the determinants of the cyclicality of public spending and of its policy implications depends on insights that are possible when focusing (independently) on economic upturns and downturns. When focusing on the determinants of procyclical expenditures, the question posed in the introduction of the paper was: 'Do marked differences exist in voter awareness in "good times" and in "bad?" Here, the evidence is that differences in awareness are salient, and that such differences strengthen the intensities of the political pressures that governments experience to increase aid expenditure in economic upturns. When focusing on foreign aid, an obvious reduction in pressure to increase government expenditure materializes when donors move into recession. 
In economic upturns governments have discretion in responding to pressures (for example, from domestic lobby groups and international agencies) to spend more on programs that are not as popular with the median voter. As evidence of the conjecture that they act strategically, this paper focuses on both the motivation and the opportunity to rely on an informational advantage in an economic upturn. Strategically, governments increase expenditures when voters are least aware of programmatic tax costs. Left-wing governments also are particularly inclined to rely on economic upturns to increase foreign aid. Governments of all political persuasions are more likely to rely on upturns the more they are "vulnerable" because of small legislative majorities (Frey and Schneider 1978, 1981). As an informational advantage is not as marked when an election is forthcoming (because electoral debates increase tax awareness), governmental foreign aid expenditures are not as procyclical in economic upturns.

In economic downturns voters are more fiscally aware. They question the "tax price" of government spending and the adequacy of specific expenditures (the inspection effect). With a more isolationist approach, the differences in voters' awareness of the benefits of foreign aid, relative to domestic expenditure (Downs 1960), become even more extreme. With falling tax revenues and difficulty relying on borrowing, governments divert expenditure from foreign programs to domestic programs.

While the evidence presented is consistent with each prediction independently, it also is the case that the pattern of evidence supports the proposition that governments act strategically. Governments time increases in less popular expenditures to occur in economic upturns. While the literature on "fiscal illusion" focuses on changes in the level of government spending, "fiscal illusion" also is relevant when analyzing the composition of government expenditure.

Turning to assessments of the policy implications of our analysis:

1. An assessment of the efficacy of foreign aid depends on awareness of procyclical expenditures in both upturns and downturns. It has been noted that, if economic cycles are correlated in donor and recipient countries, procyclical foreign aid over the economic cycle implies that "aid is not working as insurance in aid-receiving countries" (GravierRymaszewska 2012, p. 9), but the only way to confirm that aid expenditures fall in a recession is to focus independently on the cyclicality of expenditures in such downturns. $^{12}$

2. An assessment of whether donor countries meet their policy spending targets also depends on cyclicality in both upturns and downturns. In the case of the OECD, governments more than satisfied their spending targets because increases in upturns were greater than reductions in downturns. An application of the "ratcheting effect" of cyclical changes (Hercowitz and Strawczynski 2004) revealed that, on balance, cyclical changes produced a positive net increase in long-term government provision of foreign aid, but, more broadly, the outcome over any period will depend on the extent to which economic upturns and recessions occur.

Given those policy criticisms, the question is whether it is possible to introduce reform. One possibility is that each nation-state "should" independently introduce "expenditure

\footnotetext{
12 If expenditures are procyclical over the entire cycle, that pattern simply might be observed because they are very procyclical in upturns and acyclical in downturns; as such, they do not fall in a recession.
} 
rules" that apply equally in both upturns and recessions. The problem is that politicians are unlikely to have incentives to constrain the discretion they might otherwise exercise over public expenditure. An alternative approach is to raise the pressure on politicians to adopt international spending targets. In 1970, the United Nations called on member states to spend $0.7 \%$ of gross national income on foreign aid in upturns and in recessions. Vaubel (1986) argues that politicians have an incentive to respond to pressure from international organizations because they are able to blame those organizations if they introduce changes that prove unpopular. Griffith-Jones (2003) and Dreher and Vaubel (2002) refer to the blame politicians placed on international financial institutions when they adopted unpopular monetary policies.

The existence of incentives to accept expenditure constraints is important, but the prospects for reform are not unqualified. While reliance on the same expenditure target in economic upturns and in recessions will reduce the cyclicality induced by "fiscal illusion", reliance on a target defined as a proportion of gross national income will not eradicate cyclicality. Moreover, while politicians may have incentives to respond, the extent to which they are likely to respond is debateable. For example, the United Kingdom agreed in principle to the UN's 1974 target, but it was 2013 before it was achieved. The United Kingdom enshrined a duty to comply in law in 2015, but that commitment is not enforceable through the law courts ${ }^{13}$ and discussion of whether political parties will continue to adhere to the "constraint" remains on-going (Full Fact 2018). Politicians might have an incentive to respond to pressure to adopt expenditure targets, but the expenditure targets are not selfenforcing "rules".

The costs of failing to reduce politicians' discretion to rely on "fiscal illusion" in economic upturns depends on the nature of the distortion. If voters underestimate the benefits (Heinrich et al. 2016) and overestimate the costs of overseas aid (Heinrich and Kobayashi 2018), the question is whether reliance on "fiscal illusion" (to increase overseas aid) is the most efficient way of providing a merit want. Many might argue that governments should rely on the alternative policy option of providing accurate information (to correct misperceptions). Even if governments have their own policy agendas (e.g., Cusack 1997; Keech 1995; Wittman 1983), assessments of good governance are likely to depend on governmental transparency and sensitivity to the preferences of well-informed voters.

The overarching conclusion in this paper is that systematic differences exist in voter awareness of public expenditure in "good" times and in "bad". Differences in voter awareness over the economic cycle are relevant when explaining differences in the intensities of political pressures for increased government spending and they are relevant when assessing the effectiveness of such expenditures.

Acknowledgements We are grateful for the useful comments and revisions suggested by the Editor and three anonymous referees. All remaining errors remain the responsibility of the authors.

Open Access This article is distributed under the terms of the Creative Commons Attribution 4.0 International License (http://creativecommons.org/licenses/by/4.0/), which permits unrestricted use, distribution, and reproduction in any medium, provided you give appropriate credit to the original author(s) and the source, provide a link to the Creative Commons license, and indicate if changes were made.

\footnotetext{
${ }^{13}$ If the government fails to meet the target, the International Development Secretary must simply explain why to Parliament.
} 


\section{References}

Abbott, A., \& Jones, P. (2011). Procyclical government spending: Patterns of pressure and prudence in the OECD. Economics Letters, 111(3), 230-232.

Abbott, A., \& Jones, P. (2013). Procyclical government spending: A public choice analysis. Public Choice, 154(3-4), 243-258.

Abbott, A., \& Jones, P. (2016). Fiscal illusion and cyclical government expenditure: State government expenditure in the United States. Scottish Journal of Political Economy, 63(2), 177-193.

Abbott, A., \& Jones, P. (2019). Inconsistencies in the finance of public services: Government responses to excess demand. In R. Wagner (Ed.), James M Buchanan: A theorist of political economy and social philosophy (pp. 205-233). London: Palgrave Macmillan.

Akitoby, B., Clements, B., Gupta, S., \& Inchauste, G. (2006). Public spending, voracity, and Wagner's law in developing countries. European Journal of Political Economy, 22(4), 908-924.

Alesina, A., Filipe, R. C., \& Tabellini, G. (2008). Why is fiscal policy often procycllical? Journal of the European Economic Association, 6(5), 1006-1036.

Almond, G. A. (1960). The American people and foreign policy. New York: Praeger.

Andersen, A. L., \& Nielsen, L. H. W. (2010). Fiscal transparency and procyclical fiscal policy. EPRU working paper series. Retrieved May 12, 2017 from https://curis.ku.dk/ws/files/19710765/wp-1001.pdf.

Ariizumi, H., \& Schirle, T. (2012). Are recessions really good for your health? Evidence from Canada. Social Science and Medicine, 74(8), 1224-1231.

Bergstrom, T. C., \& Goodman, R. P. (1973). Private demands for public goods. The American Economic Review, 63(3), 280-296.

Blundell, R., \& Bond, S. (1998). Initial conditions and moment restrictions in dynamic panel data models. Journal of Econometrics, 87(1), 115-143.

Borcherding, T. E., \& Deacon, R. T. (1972). The demand for the services of non-federal governments. The American Economic Review, 62(5), 891-901.

Craig, E. D., \& Heins, A. J. (1980). The effect of tax elasticity on government spending. Public Choice, 35(3), 267-275.

Cusack, T. R. (1997). Partisan politics and public finance: Changes in public spending in the industrialized democracies, 1955-1989. Public Choice, 91(3-4), 375-395.

Dabla-Norris, E., Minoiu, C., \& Zanna, L.-F. (2015). Business cycle fluctuations, large macroeconomic shocks, and development aid. World Development, 69(C), 44-61.

Darby, J., \& Melitz, J. (2008). Social spending and automatic stabilizers in the OECD. Economic Policy, 23(56), 716-756.

Dell'Anno, R., \& Mourao, P. (2011). Fiscal illusion around the world: An analysis using the structural equation approach. Public Finance Review, 40(2), 270-299.

Dell'Anno, R., \& Dollery, B. (2014). Comparative fiscal illusion: A fiscal illusion index for the European Union. Empirical Economics, 46(3), 937-960.

Dollery, B. E., \& Worthington, A. C. (2006). The empirical analysis of fiscal illusion. Journal of Economic Surveys, 10(3), 261-297.

Downs, A. (1957). An economic theory of democracy. New York: Harper.

Downs, A. (1960). Why the government budget is too small in a democracy. World Politics, 12(4), 541-563.

Dreher, A., \& Vaubel, R. (2002). Does the IMF cause moral hazard and political business cycles? Evidence from panel data. University of Mannheim Institut fur Volkswirtschaftslehreund Statistik. Working paper. Retrieved September 7, 2019 from https://EconPapers.repec.org/RePEc:wpa:wuwpi f:0207002.

Frey, B. S., \& Schneider, F. (1978). An empirical study of politico-economic interaction in the United States. The Review of Economics and Statistics, 60(2), 174-183.

Frey, B. S., \& Schneider, F. (1981). A politico-economic model of the U.K.: New estimates and predictions. The Economic Journal, 91(363), 737-740.

Fuchs, A., Dreher, A., \& Nunnenkamp, P. (2014). Determinants of donor generosity: A survey of the aid budget literature. World Development, 56(C), 172-199.

Full Fact. (2018). UK spending on foreign aid. Retrieved October 3, 2019 from https://fullfact.org/econo my/uk-spending-foreign-aid/.

Gavin, M., Hausmann, R., Perotti, R., \& Talvi, E. (1996). Managing fiscal policy in Latin America and the Caribbean: Volatility, procyclicality, and limited creditworthiness. IDB working paper no. 269. Retrieved September 2, 2019 from https://ssrn.com/abstract=1815955. 
Gravier-Rymaszewska, J. (2012). How aid supply responds to economic crises: A panel VAR approach. WIDER working paper no. 2012/25. Retrieved July 6, 2012 from https://www.wider.unu.edu/publi cation/how-aid-supply-responds-economic-crises.

Griffith-Jones, S. (2003). International financial stability and market efficiency as a global public good. In I. Kaul, P. Conceição, K. Le Goulven, \& R. U. Mendoza (Eds.), Providing global public goods: Managing globalization (pp. 435-454). Oxford: Oxford University Press.

Gruber, J. (2004). Pay or pray? The impact of charitable subsidies on religious attendance. Journal of Public Economics, 88(12), 2635-2655.

Halland, H., \& Bleaney, M. (2011). Explaining the procyclicality of fiscal policy in developing countries. University of Nottingham, CREDIT discussion paper 11/09. Retrieved April 8, 2016 from https://ideas.repec.org/p/not/notcre/11-09.html.

Health Foundation. (2017). What does the public think about NHS and social care services? Retrieved August 8, 2017 from https://www.health.org.uk/sites/health/files/Polling2017_web.pdf.

Heinrich, T., \& Kobayashi, Y. (2018). How do people evaluate foreign aid to 'nasty' regimes? British Journal of Political Science. https://doi.org/10.1017/S0007123417000503.

Heinrich, T., Kobayashi, Y., \& Bryant, K. A. (2016). Public opinion and foreign aid cuts in economic crises. World Development, 77(C), 66-79.

Hercowitz, Z., \& Strawczynski, M. (2004). Cyclical ratcheting in government spending: Evidence from the OECD. The Review of Economics and Statistics, 86(1), 353-361.

Higgs, R. (1987). Crisis and leviathan: Critical episodes in the growth of American government. Oxford: Oxford University Press.

Hossain, B., \& Lamb, L. (2012). Price elasticities of charitable giving across donation sectors in Canada: Is the tax incentive effective? ISRN Economics, 2012, 1-6.

Jones, P., \& Hudson, J. (1996). The quality of political leadership: A case study of John Major. British Journal of Political Science, 26(2), 229-244.

Kaminsky, G. L., Reinhart, C. M., \& Végh, C. A. (2004). When it rains, it pours: Procyclical capital flows and macroeconomic policies. NBER Macroeconomics Annual, 19, 11-53.

Katsimi, M., \& Sarantides, V. (2012). Do elections affect the composition of fiscal policy in developed, established democracies? Public Choice, 151(1-2), 325-362.

Keech, W. R. (1995). Economic politics: The costs of democracy. Cambridge: Cambridge University Press.

Lane, P. R. (2003). The cyclical behaviour of fiscal policy: Evidence from the OECD. Journal of Public Economics, 87(12), 2661-2675.

Lane, P. R., \& Tornell, A. (1996). Power, growth, and the voracity effect. Journal of Economic Growth, 1(2), 213-241.

Milner, H., \& Tingley, D. (2013). Public opinion and foreign aid: A review essay. International Interactions, 39(3), 389-401.

Modrek, S., Stuckler, D., McKee, M., Cullen, M. R., \& Basu, S. (2013). A review of health consequences of recessions internationally and a synthesis of the US response during the great recession. Public Health Reviews, 35(1), 1-33.

Nickell, S. (1981). Biases in dynamic models with fixed effects. Econometrica, 49(6), 1417-1426.

Oates, W. E. (1988). On the nature and measurement of fiscal illusion: a survey. In G. Brennan, B. Grewal, \& P. D. Groenewagan (Eds.), Taxation and fiscal federalism: Essays in honour of Russell Matthews (pp. 65-82). Sydney: Australian National University Press.

OECD. (2018a). General government accounts, SNA 2008 (or SNA 1993): Government expenditure by function. Retrieved October 21, 2019 from http://dx.doi.org/10.1787/data-00019-en.

OECD. (2018b). National accounts of OECD countries. Retrieved October 21, 2019 from http://dx.doi. org/10.1787/na_vol_1-2010-en-fr.

OECD. (2018c). OECD economic outlook: Statistics and projections. Retrieved October 21, 2019 from http://dx.doi.org/10.1787/05b705e7-en.

Peacock, A. T., \& Wiseman, J. (1961). Introduction and summary. In A. T. Peacock \& J. Wiseman (Eds.), The growth of public expenditure in the United Kingdom (pp. 1-11). Princeton: Princeton University Press.

Peloza, J., \& Steel, P. (2005). The price elasticities of charitable contributions: A meta-analysis. Journal of Public Policy \& Marketing, 24(2), 260-272.

PIPA. (2001). Americans on foreign aid and world hunger: a study of U.S. public attitudes. Retrieved October 21 , 2019 from https://drum.lib.umd.edu/bitstream/handle/1903/10188/ForeignAid_Feb01 rrpt.pdf? sequence $=4 \&$ isAllowed $=y$.

Ramji, S., \& Quiñonez, C. (2012). Public preferences for government spending in Canada. International Journal for Equity in Health, 11(1), 64-74. 
Rogoff, K. (1990). Equilibrium political budget cycles. American Economic Review, 80(1), 21-36.

Scartascini, C., Cruz, C., \& Keefer, P. (2018). The database of political institutions 2017 (DPI2017). Retrieved October 21, 2019 from http://dx.doi.org/10.18235/0001027.

Soroka, S. N., \& Lim, E. T. (2003). Issue definition and the opinion-policy link: Public preferences and health care spending in the US and UK. The British Journal of Politics \& International Relations, 5(4), 576-593.

Steinberg, R. (1990). Taxes and giving: New findings. VOLUNTAS: International Journal of Voluntary and Nonprofit Organizations, 1(2), 61-79.

Talvi, E., \& Végh, C. A. (2005). Tax base variability and procyclical fiscal policy in developing countries. Journal of Development Economics, 78(1), 156-190.

Tornell, A., \& Lane, P. R. (1999). The voracity effect. American Economic Review, 89(1), $22-46$.

U.S. Energy Information Administration. (2019). Crude oil prices: West Texas Intermediate (WTI)—Cushing, Oklahoma [DCOILWTICO]. Retrieved October 21, 2019 from https://fred.stlouisfed.org/series/ DCOILWTICO.

Vaubel, R. (1986). A public choice approach to international organization. Public Choice, 51(1), 39-57.

Wilson, S., Meagher, G., \& Hermes, K. (2012). A new role for government? Trends in social policy preferences since the mid-1980s. In J. Pietsch \& H. Aarons (Eds.), Australia: Identity, fear and governance in the 21st century (pp. 107-131). Canberra: Australian National University Press.

Wittman, D. (1983). Candidate motivation: A synthesis of alternative theories. American Political Science Review, 77(1), 142-157.

Woo, J. (2009). Why do more polarized countries run more procyclical fiscal policy? The Review of Economics and Statistics, 91(4), 850-870.

Publisher's Note Springer Nature remains neutral with regard to jurisdictional claims in published maps and institutional affiliations. 